\title{
TRASH MANAGEMENT USING “ASSET BASED COMMUNITY-DRIVEN DEVELOPMENT" TO TURN GARBAGE INTO COMMODITY WITH CREATIVE- ECONOMIC VALUE
}

\author{
Dr. Subiyantoro, M.Ag. ${ }^{1}$, Siti Zubaidah, M.Pd. ${ }^{1}$, Taufiq Ahmad Syauqi, S.Psi. ${ }^{2}$ \\ ${ }^{1}$ Lecture at State Islamic University Sunan Kalijaga Yogyakarta \\ ${ }^{2}$ Student at State Islamic University Sunan Kalijaga Yogyakarta \\ Email: sbytoro@ymail.com
}

\begin{abstract}
Abstrack
Education is still not answer the expectations of the people, they always questioned the relevance of education by a variety of community needs in the dynamics of economic, social, political, legal and cultural. A new paradigm of education changes to quality (quality oriented) is one of the strategies to achieve educational excellence in meeting the demands and needs of the community. Therefore necessary institutional strengthening capacity (Capacity Building) of the Madrasah. Community empowerment-based creative economy programme through the madrasah were necessary. One of the selected empowerment utilizing waste products worth selling. On the other side of the creative economy approach is thew into madrasah quality improvement effort in answering the needs of the community in the era of economic globalization. This research aims to improve the quality of economic empowerment through creative schools that work together with the community. The subject of this research is MTs. N. 5 KulonProgo, located in the village and brought in, (environmental mountain tourism Suroloyo), Ma'arif myocardial infarction and Pagerharjo village (pagerharjo village Government Center neighborhood is located), myocardial infarction and Ngargosari Ma'arif, community mothers dukuh Ngargosari Ngaliyan, Dukuh Trayu Community Ngargosari. The research method used was applying a Research and Development (R\&D), with regard to data collection Techniques: observation, indept interview. The strategy of training/mentoring in applying the model of "service learning", with the approach of andragogy. The data analysis used models, Miles and Huberman and Spradley. The results of this study indicate that the training provided to communities and schools to cultivate waste into creative stuff that has value has managed to provide the skills knowledge and abilities are new to them. The subject is able to make a variety of creative stuff from the trash so that gave rise to the idea for the creation of the trash bank as the flagship program in the schools to have better quality.
\end{abstract}

Keyword: Trash Management, creative-economic commodity 


\section{INTRODUCTION}

Community empowerment strategies in the perspective of asset based community-driven development $(A B C D)$, assets are everything. Not limited to asset function as social capital, but also as embryonic social change. In addition, asset also serves as a bridge to build relationships with outside parties. In such a view, then the community is required for sensitive and sensitive to the existence of the asset that is around them. The paradigm of the "need for community is sensitive to the presence of assets" can be meant for community elements that exist in the community and also the elements of the community for formal education. In community empowerment, the sensitivity of the community to the existence of the assets required partnerships with outside parties, because not all the community aware of the ownership of a valuable asset, which could be developed into something that economic value

The College has an important role in empowering communities one of them through the partnership program in the form of real working course of lectures (CCN). College partnership program with the community required to initiate activities that foster creative potential of citizens without having to patronize community. Therefore this devotion album research developed a model of "service learning" for the elements of the community, as well as "service learning" madrasah and build partnerships between community both. This model of community empowerment program in order for bertjuan-based Creative Economy developing in a sustainable way can exist. On the other hand, the madrasa could develop a program-based management school/Madrasah by developing a program of a local charge.

Creative economy approach in line with the Government's efforts have established a creative economy Agency ("Bekraf") which serves to 
optimize the potential-potential that is owned by any area especially pedesan areas. This opportunity is certainly brings great challenges for Islamic institutions to respond to the creative economy programme implementation policy. The role of Government in the national program of creative economy programme include the provision of budget funds.

The success of the creative economy programme undertaken by the Government since the year 2015 until now seem to have a great influence for economic growth of the nation. Creative economy approach can be done with the utilization of used goods managed be worth selling. Used items such as garbage has always been a problem that still need solutions from a variety of perspectives. Creative economy approach in the management of madrasah has a purpose-based so that students have an understanding of the waste and make use of them. On the other hand the knowledge menyongkong community empowerment around the madrasa.

The existence of education still felt disappointing expectation of the community is so great, they always questioned the relevance of education by a variety of community needs in the dynamics of economic, social, political, legal and cultural. A new paradigm of education changes to quality (quality oriented) is one of the strategies to achieve educational excellence in meeting the demands and needs of the community. This is where the necessary strengthening of the institutional capacity (Capacity Building) of the Madrasah that exists in the middle of the community.

Improved quality of education reform through decentralization policies in the form of Autonomy "School-based management/Madrassa" (MBS/M), supposed to be the opportunity for madrasah to create, innovate and improvise. Educational reform in the form of the MBS/M in the business of quality improvement is responsive to the needs of the community. The 
effort can be conducted by the madrasah can be either increased skill learners and teachers, thus contributing positively to the community. One form of such efforts is to answer the challenges of the globalization of the industry with the creative economy approach.

Community empowerment-based creative economy programme through the madrasah were necessary. One of the selected empowerment utilizing waste products worth selling. On the other hand the economic approach is thew the creative efforts of madrasah quality improvement in answering the needs of the community in the era of economic globalization.

Based on the description, the author intends to conduct research with the title " Trash Management Using "Asset Based Community-Driven Development" to Turn Garbage Into Commodity With Creative-Economic Value".

\section{Review Of The Literature}

Some research about the theme associated with the empowerment of the community with the creative economy programme are as follows:

The results of research conducted by Ahmad Hisham As'ari, about creative economy-based community empowerment through training product manufacturing waste coffee tree trimmings (a case study on the community of poor coffee plantations in the village of Harjomulyo Sub-district Silo, Jember Regency). The results of his research that the process of empowerment of the creative economy-based society is made through training activities of making products from waste trimmings coffee trees. The obtained impacts i.e., skills improvement of society and has a potential revenue from waste coffee trees if the product was used as an ornament. 
Other studies with the title of the strategy of community empowerment through creative economy innovation in tackling poverty in Pasuruan, by Bagus Udiansyah, et al 2016 Social Humanities journals. No. 4 vol. 19. The results of research that the empowerment of communities by optimizing the local HR with $5 \mathrm{p}$ : strategy, strengthening, protection, supporting, and maintenance. The role of the scholar: driving the creation of HUMAN RESOURCES development as well as the driving force and creative utilization of science and technology.

On the research of written by Merla Liana herawati entitled Community economic empowerment through coconut shell handicrafts in Bantul, the economic empowerment of the community in the area done by stages namely creating circumstances develop the potential of society, strengthening the economy, develop the potential of the community. As for the positive impact that is, reduce unemployment and increase people's income.

In another study published in the journal of Socialite 2016 , vol 8, no 1 by NoningWatcharadkk, entitled community empowerment through creative economy businesses Bratasena eggs salt low cholesterol indicates that the method used for this is empower the cultivation of laying duck through (1) training to members of the two groups in aspects of production and management aspects, (2) make a duck laying cages, demplot and (3) Mentoring cultivation and accompaniment of making salted eggs.

Research conducted by Ihsan, Djailani year 2014 in the journal education administration about implementation of school-based management in improving the quality of education in the State of SD 62 Banda Aceh, show that the leadership of the head of school in improving the quality of education in the State of SD 62 Banda Aceh is done by adjusting 
the policy rules and objectives of the school principal, mixing work system with the resources of the school in order to obtain a high achievement with a focus on the development of quality learners. MBS Implementation steps, performed with the stages of socialization, formulating the vision, mission and objectives of the school, identify the challenges of school, and SWOT analysis.

In those studies have in common, namely the empowerment of the community in the field of creative economy. Are there yet is how the institution contributed in it. Then the research attempted to associate the community empowerment with the madrasa, in an effort to improve the quality of student SERVICE LEARNING in order to have a positive contribution in improving the welfare of rural communities through creative economy programme. The development of this creative economy operates on the "action" of cooperation between the Community aims at empowering the madrassa with elements of both. So the program can be sustained, as it is handled by the institution.

\section{The Concept Of Community Empowerment}

According To The Moh. Ali Aziz et al (2005) is a concept of empowerment the focus is power. Empowerment is the process substantially break (break down) of the relationship between subject and object. This process is concerned with the recognition of the subject will be the ability or resources owned object. In an attempt to empower communities, according to Gunawan Sumodiningrat, (2002) can be seen from two sides, first, creating an atmosphere or climate that allows developing community potential (enabling). Here is the introduction of the turn point that every human being, every society, has a potential that can be developed. That is, there is no 
society that is totally without power, because if so it will be extinct. Empowerment is an effort to build up power, push, motivate, and raised awareness of the potential of its own as well as working to improve it. Second, strengthening the potential or power of community (empowering).

According to Randy R. Wrihatnolo (2007) power in the context of a society is the ability of individuals and communities in the form of building capability of society concerned. The community that most of its members are physically and mentally healthy, educated and powerful as well as innovative, certainly has a high capability. Capability of the community are being part that allow the public to survive and dynamic in the sense of developing themselves and achieve progress.

Based on the above description it can be concluded that the community empowerment is creating the climate and develop the potential of the community to become an independent community. Develop the community by digging and develop existing potential

\section{The concept of Managed-based school/Madrasah (MBS/M)}

Dally (2010), defines that MBS is a management model that gives autonomy or independence to the school and encourages decision making partisipasif involving directly all the citizensthe school. Mulyasa, (2012), interpret the MBS is as a form ofalternative management of school decentralization in the framework of education, markedwith the authority of a wider decision making at the school level, public participation is relatively high, in the framework of the national education policy. Rohiat (2010) States that MBS is as a management model that provides autonomy/flexibility to schools, encourage participation directly from the citizens of the school and the community in improving the quality of the school. 
Based on the above description it can be concluded that school-based managed is a form of school autonomy in managing educational institutions in order to achieve the quality of qualified and able to comply with the conditions of the local community. School/madrasah has the discretion to develop the school/madrasah in accordance with the existing potential in school/madrasah and the environment of the community.

The concept of Asset Based Community-driven Development ("ABCD") and the Creative Economy

\section{Asset Community-driven Development (“ABCD”)}

The concept of asset based community-driven development is community empowerment model with maximizing potential, assets, strengths and pendayagunaannya independently. "ABCD" pursues the attainment of an order of social life which makes the community as the perpetrator of the decisive development in its environment (CommunityDriven Development)

The principle of empowerment model "ABCD" include: (1) make use of existing, "half full and half empty"; focusing on the empowerment that has existed/has been owned. (2) all got a potentiality (No. Lucha has nothing), all potential and all can contribute. (3) participation (partipation). (4) the partnership (partnership), in collaboration with shared objectives over the deal, the principle and the role of each. (5) a positive Deviation (positive devience), approaches to individual and social behavior changes based that in every community there is a pull strategy for success that is not common. Society basically already have a solution, they are the best experts to solve their own challenges. (6) from the Community (endogenous), referring to the 
principal goal of strengthening local communities. (7) to the source of energy (heliotropic).

\section{Creative Economy}

Suryana (2013) the Creative Economy is the wave of the new economy that was born at the beginning of the 21st century. The wave of the new economy is giving priority to the intellectual as wealth that can create money, employment, income and welfare. The core of the creative economy lie in the creative industries that is Industry driven by the creators and innovators.

Ridolof w. Batilmurik (2016) stated that the development of the local economy is a concept of economic development based on the utilization of local resources in a society, human resources, natural resources, and resources institutional. Utilization of the resources committed by the community itself alongside local government institutional groups or community-based. To achieve these goals, local government and the community should jointly take the initiative in the development of the local economy can be done through a partnership forum. While the partnership itself has significance that in the process of landscape planning, implementation and evaluation of the program there is a togetherness that synergistic between Government, the business world and society

\section{Research methods and procedures}

\section{Research Methods}

Research methods in research/consecration by invoking Reseach and Development (R\&D), Research methods in research/consecration by invoking Reseach and Development (R\&D), with regard to data collection Techniques: 
observation, indept interview. The strategy of training/mentoring in applying the model of "service learning", with the approach of andragogy. The data analysis used models, Miles and Huberman and Spradley. The data analysis process include: reduction, data display, and drawing/veryvicationconclution. The stages of data analysis (model Spradley) include: Domain Analysis, Tacsonomic Analysis, Componential Analysis, Discovery of Cultural Themes

\section{The Data Source}

Creative economy development objectives through waste management for madrasah and this society will be focused on:

- MTs. N. 5 KulonProgo, located in the village and brought in, (environmental mountain tourism Suroloyo)

- MI Ma'arif village Pagerharjo (environmental governance Centre village pagerharjo is located)

- MI Muhammadiyah Nglinggo Pagerharjo (environment natural tea garden Nglinggo Pagerharjo) 
Mechanism of "Service Learning" Empowered Society based on Madrasah Creative Economy Program

1. Scheme of "Service Learning” Program

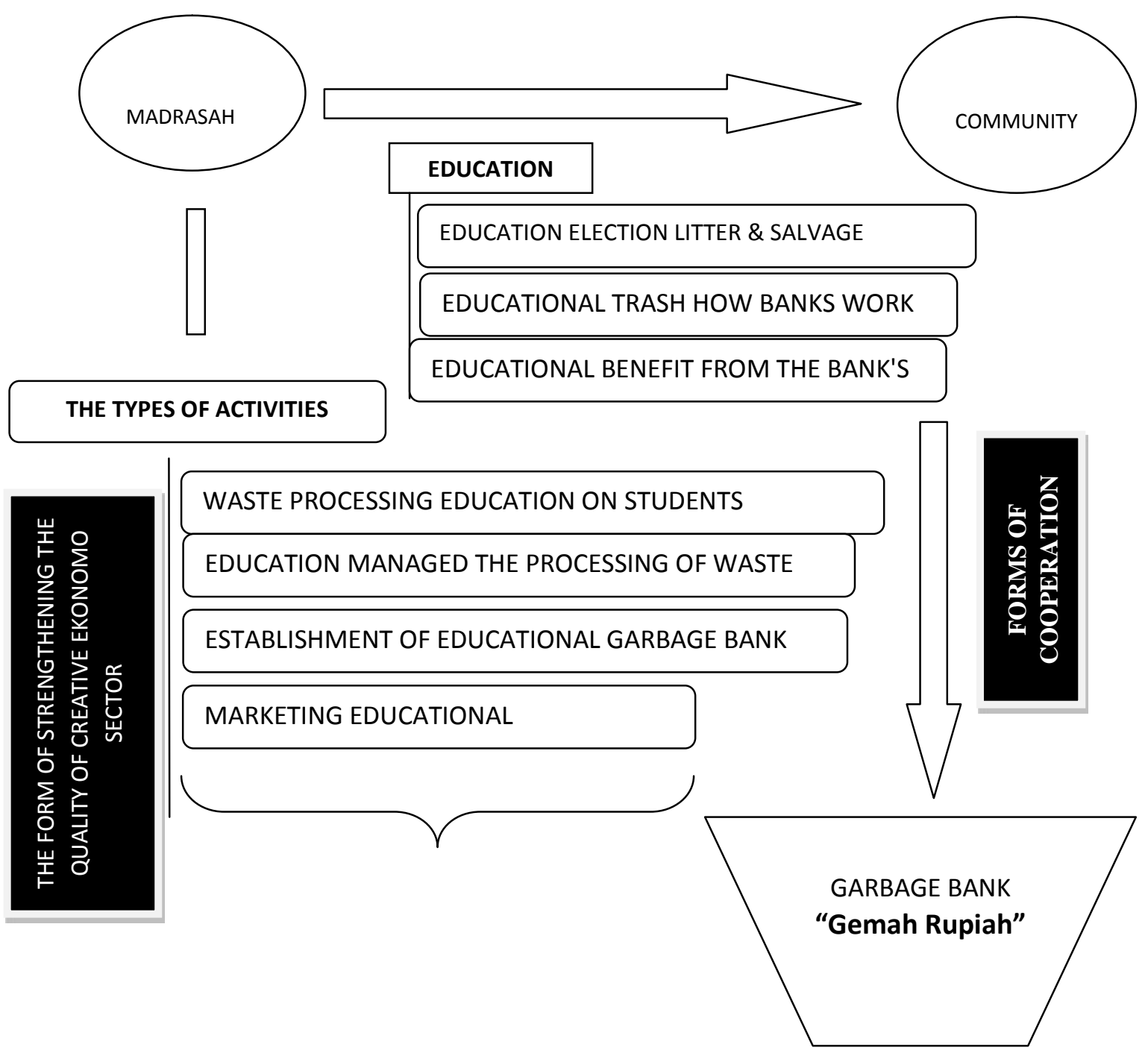


2. The Framework Of "Service Learning" Creative Economy Development

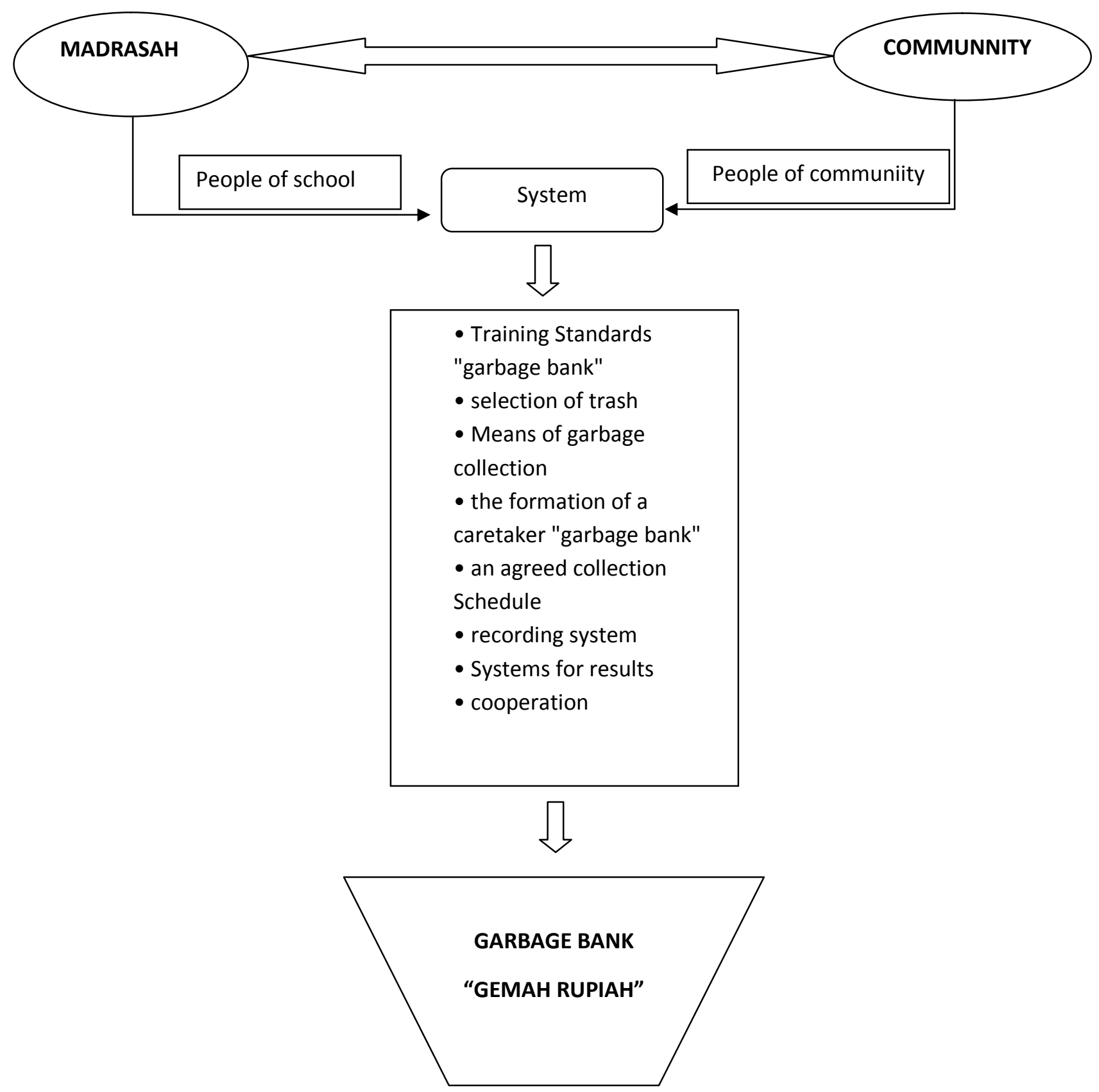


3. implementation of "Service Learning" Creative Economy Development

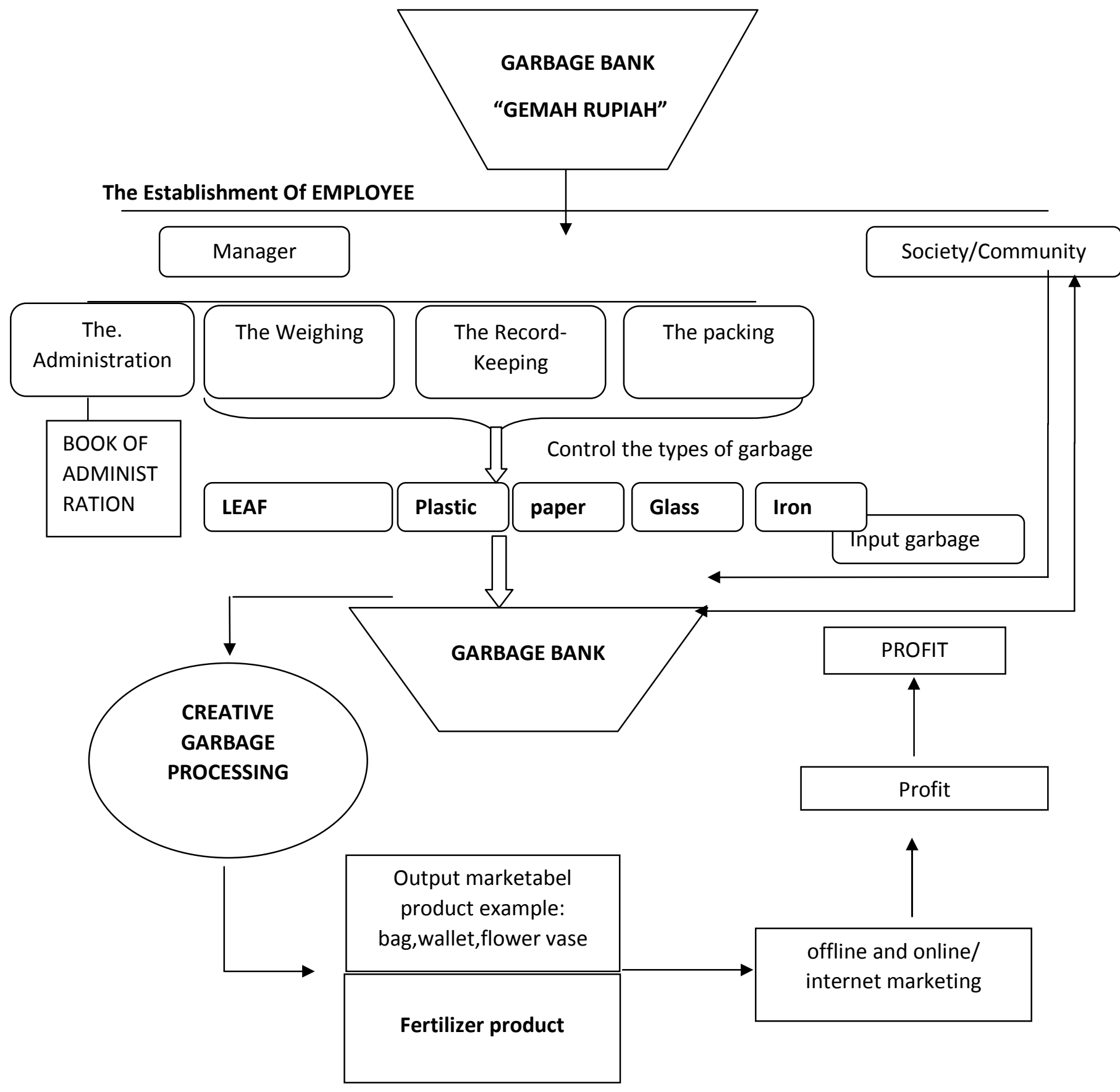




\section{Research results}

every community including the school community has the potential as well as the asset that can be empowered. One of these is a potential motivation for learning. On the community that became the subject of the study, the researchers found a huge motivation on them to improve the welfare of living through the processing of waste into a product that has value. Based on the results of interviews, researchers found that motivation can be known from the attitude of the public enthusiasm in following a wide range of creative product processing training program to produce fiber glass product which organized by the head of the host. But the motivation is reduced because the product they produce doesn't have a great selling points. On the other hand the way the processing of products and raw materials to make products very difficult to acquired by the community. One example of the difficult material retrieved is fiber, ceramics and glass. The difficulty is influenced by demographic factors of residence community and economic factors.

The first factor is the demographic factor. The demographic factor is a major factor that made the community motivation in the processing of a product that has value be decreased. In demographics, community residing in the mountains area with a lot of trees and fields. So to get the raw materials such as glass, ceramics to create a product that is worth selling is very difficult. These factors make it the community's motivation to improve the welfare of living less maximum.

The second factor is the economic factor. The economic factor is the factor the ability of purchasing power on site research. Purchasing power to buy products from ceramics, or glass are still less well. This makes the 
preparation of raw material for the products worth selling of glass or ceramic is very limited.

At school, the motivation to study waste treatment are very high. It is based on the results of the interviews conducted by the researcher. Researchers found that one of the problems faced by the school are a waste problem. Organic waste such as leaves being the main problem because every day a lot of the leaves of a tree which collapsed so the school environment becomes dirty. The school is already working to find a solution in dealing with organic waste, but still has not found a good solution. With regard to plastic trash in the trash can school, so far has not found a solution to address it. The teachers are already trying to make plastic waste into a product worth selling through extracurricular activities. But the work done, it is still not done. One of the main factors is the inability to create a product that is worth selling and how to choose the raw material that is capable of being a product worth selling.

Some of the factors that existed in the community community school and MI Ngaliyan dukuh Ma'arif and MTs. N. 5 Tags into authorized capital to be given training and empowerment. The training given to community and school community dukuh Ngaliyan MI Ma'arif and MTs. N. 5 Tags implemented together in one room. Based on the results of research and empowerment training for waste treatment given to the subject of research. Researchers found that the empowerment program training processing of waste into stuff that has value by all research subjects responded with enthusiasm. The response can be known from the research subjects who wish to deepen training processing waste into items of creative goods can be sold. The subject is able to make products such as bags, wallets with the guidance of a coach. 
On the subject of children such as students from Madrasah Ibtidaiyah (MI) Ma'arif, they are able to make flowers out of plastic waste. They enthusiastically asked the coach if in the process of completing the improvements experienced difficulties. As for the students of MTs. N. 5 Kulon progo they were able to create dishes made of plastic drinking water. Based on the results of observation and interviews conducted by researchers at the students, all the students are interested in learning to make money selling products from garbage. Among those delivering the training program so that processing waste into a product worth selling to be the activities of esktrakurikuler in sekohan. Another student says, wants to create interest of housing was sold to his friends or neighbors House.

The results of training on the subject of the students showed that training processing waste into a product that has value can cultivate interest students to think creatively in utilizing waste into products. On the other hand, the training can foster entrepreneurial soul early on. Processing waste into a product worth selling to increase self confidence in students. Confidence can be seen from the results of the products they make are to be presented to all the participants and wishes to sell his product to friends at school.

On mothers who are members of their host community Ngargosari Ngaliyan very enthusiastic on the program processing waste into products that can be sold. They have been able to make wallets and floral. This is motivating the other to learn processing waste into products that can be sold. Ngaliyan dukuh community feel to find solutions in making a product that has value. Solutions that make them increase his motivation in realizing the welfare of living is the ease of finding the raw material i.e. waste to be 
processed into a product that has value. The training provided was able to motivate the mothers to establish the bank of litter in the community. Researchers found a sense of the enthusiasm of mothers who are in community Ngaliyan Ngargosari seen from the small discussion forums they do after they complete the task they are working on from the coach. On such a small forum discuss about mutual agreement to visit the residence coach to study more seriously in the processing of waste into a product that has value.

On community Trayu the host Ngargosari which was attended by both men. They are more interested in the sewage treatment waste into compost. Training of processing waste into compost can be practiced by fathers and well managed. Their enthusiastic attitude visible when in the processing of waste into compost has trouble in the middle of the road, they are not afraid to ask the coaches. Knowledge of pengolaan waste into compost into new knowledge owned by the fathers so that it can help reduce the use of chemical fertilizers.

Researchers found the subject of the host male Trayu Ngargosari look eager in the field of processing waste into compost. The spirit can be seen from the small discussion conducted by the male subject when discussing materials that could be used to make compost. Training to make the compost also brings out the soul of enterprenur the subject of men. The entrepreneur's soul can be seen in the calculation of cost of production and profit selling compost is done by the male subject with coach. The compostmaking training also gave rise to the idea of some teachers at the school who follow the training, to create ektrakurikuler activities program at the school. The extracurricular activities are held aiming to give knowledge to students 
the importance of organic waste to the crops as well as train the skills of students cultivation.

As for the bank's trash program socialized to the participants have provided new knowledge. The subject of the research says very interested with the program the bank trash to be carried out between the school and the community. The school will apply the existence of junk bank became the hallmark of the school so that the school has a high quality compared to other schools. The bank's program of garbage is also considered by the school as a way to educate children care about the environment as well as grow the soul enterprenuer through creative ideas from the processing of waste.

The bank's program of garbage for the subject of the community also make them interested to improve the welfare of their lives through processing waste into a product that has value. On the other hand the training about the program the bank trash can also regenerate the soul of enterprenur society. The existence of the bank trash in the community considered to be able to educate people to be more creative in making a product that has value as well as providing awareness to the community about the health of the environment.

Researchers concluded that the training provided to communities and schools to cultivate waste into creative stuff that has value has managed to provide the skills knowledge and abilities are new to them. To support the knowledge and skill which, researchers give the goods that are the stimulus as a tool for making compost as well as examples of plastic goods into creative stuff that has value. The giving of goods are the stimulus aims to empower the skills that they have learned thus making banks litter will be done properly. 
Community empowerment through the course of the processing of waste into the selling value of products can be done by working with the school. The school will have a good progress in improving the quality of education with local content program. Educational enhancement through program with local content such as processing the waste into a product that has value can be the hallmark to answering the economic challenges. With regard to the community, the program processing waste become a creative way to improve the welfare of their lives.

\section{Conclusion}

Trash management using "asset based community-driven development" to turn garbage into commodity with creative-economic value programme is able to be implemented. Empowerment aims to optimize the potential of or asset that is owned by the community. Empowerment is exercised through school or madrassa in order that the school has a good quality. On the other hand, the school will answer the expectations of the community for being a winning school or madrassa as well as foster new skiil for students. Among the skills that can be grown through this empowerment program is entrepreneurial skill. Entrepreneurial skill can be seen from the ability of the students in utilizing waste into a product that has value. For example, product bags, purses, flower vase, compost and so on. As for the community can have the knowledge and skills that new economic empowerment program with the creative. Through this empowerment programs, schools and communities can work together reduces waste in the environment. As for the existence of such cooperation can be done with the process of the establishment of the bank trash. The existence of the bank will be a means of garbage in produces products that have value. 
Last but not least, the researchers need to thank Research and Community Service Institution (LP2M) of State Islamic University Sunan Kalijaga for providing research funding that is from BOPTN 2018 funds. We hope that what we have done can give a great benefit to many people. 


\section{BIBLIOGRAPHY}

Ahmad Hisham As'ari, et al. 2015. Community empowerment through creative economy based training product manufacturing waste coffee tree ornaments: in the community of poor coffee plantations, Jember). The research of PEDAGOGY of the University of Jember Nice udiansyah, et al. 2016. The strategy of community empowerment through creative economic Innovations in poverty reduction (case study Industry kerajina looms in Pasuruan, not machines). Social Humanities Journals. No. 4 vol. 19

Batilmurik, Ridolof w. 2016. The development of Creative economic Model for society Kupang of East Nusa Tenggara. Journal of Applied Research, Managed vol. 1 No. 1

Dally, D. 2010. An approach in the implementation of school-based management. Bandung: Teen Rosdakarya.

Ihsan, Djailani. 2014. The implementation of school-based management in improving the quality ofeducation in SDN 62 Banda Aceh. Journal Of AP's Post

Bachelor's degree University of Syiah Kuala. Volume 4. November. 2014. The number 2

Spradley, James p. (1979). The etnographic intervew. New York: Harcourt Brace Jovanovich College Publishers.

Sumodiningrat, g. 2002. Community empowerment and social safety net. Jakarta:Gramedia.

Suryana. 2013. The Creative Economy: Economists (changing Idea and creating opportunities.Salemba Jakarta: Four). Synopsis (back cover) 
Listijaningsih dkk. The effectiveness of the implementation of the MBS in Experiment 2 and SDN SDN Ngringin subdistrict of Depok Sleman Regency. Journal Of Manejemen Education Accountability. Volume. 3 April 2015. Number 66-81. Journal on line UNY.

Research institutions and community services (LP2M) UIN Sunan Kalijaga. GUIDELINES FOR COLLEGE INTERNS REAL (CCN) INTEGRATIONINTERCONNECT. The year 2017

Mulyasa, Enco. 2012. The school-based management:: Bandung: Teen Rosdakarya. Things: 177.

MOH. Ali Aziz, et al. 2005. Dawah Community Empowerment: The Paradigm Of Action Methodology. Yogyakarta: Pustaka Boarding School

Merla Liana herawati. 2001. the economic empowerment of the community through the coconut shell handicraft: on Display, Bantul. Faculty Research Da'wah UIN Sunan Kalijaga and communication.

Noning Watchara dkk. 2016. Community empowerment through creative economy businesses Bratasena eggs salt low cholesterol. Socialite journal vol 8, no 1, Rohiat. 2009. The School Management-basic theory and practice. Bandung: Refika

Randy r. Wrihatnolo, 2007. Management of empowerment: an introduction and guide for community empowerment, Jakarta: PT Elex Komputindo, Parocha, Mita a. Esguerra Jr., Ernesto | Celeste G. Hular. 2015. Solid waste management Program: The Grade School Experience. LetranCalamba Journal of Institutional Research and Development. Vol. 1 No. 2 